\title{
The treatment of metastatic non-small cell lung cancer in the elderly: an evidence-based approach
}

\section{David E. Dawe ${ }^{1 *}$ and Peter Michael Ellis ${ }^{2}$}

' Section of Hematology and Medical Oncology, Department of Internal Medicine, University of Manitoba, Winnipeg, MB, Canada

${ }^{2}$ Department of Oncology, McMaster University, Hamilton, ON, Canada

\section{Edited by:}

Vera Hirsh, McGill University Health

Centre, Canada

Reviewed by:

Sacha I. Rothschild, University

Hospital Basel, Switzerland

Ajeet Gajra, SUNY Upstate Medical

University, USA

\section{*Correspondence:}

David E. Dawe, Section of

Hematology and Medical Oncology, Department of Internal Medicine,

University of Manitoba, ON

2052 - CancerCare Manitoba, 675

McDermot Avenue, Winnipeg, MB

R3E OV9, Canada

e-mail:david.dawe@

cancercare.mb.ca
An increasing proportion of patients with advanced non-small cell lung cancer (NSCLC) are over 70 years old, raising unique challenges for treatment decision-making. While these patients are underrepresented in clinical trials, there is an emerging body of evidence associated with this group. The lesson of comprehensive geriatric assessment is that chronological age does not always correlate with physiological age and a variety of important co-morbidities and geriatric syndromes can go undetected in a typical history and physical. These co-morbidities and expected physiologic changes due to aging complicate decision-making around appropriate treatment. This review discusses geriatric assessment in elderly cancer patients and evaluates the current evidence for chemotherapy and targeted therapy for patients with advanced NSCLC aged $\geq 70$ years.

Keywords: non-small cell lung cancer, chemotherapy, elderly, geriatric assessment, targeted therapy

\section{INTRODUCTION}

The number of seniors in Canada is projected to more than double between 2005 and 2036 (1) and global life expectancy has increased continuously over the last 40 years (2). Forty-three percent of cancers in 2010 were diagnosed in patients 70 years or older (3). Therefore, barring a significant change in cancer incidence, the absolute number of cancers diagnosed in elderly patients can be expected to increase substantially both in Canada and worldwide.

Worldwide, lung cancer is the leading cause of cancer-related mortality and by 2010 was the fifth overall leading cause of death $(4,5)$. Eighty-five percent of diagnosed lung cancer patients have non-small cell lung cancer (NSCLC) $(6,7)$. The median age of diagnosis is 70 years and has been increasing $(7,8)$. Lung cancer is therefore a disease of older adults and up to $70 \%$ of patients are diagnosed in advanced stage, where the standard treatment is systemic therapy (8).

This advanced age is an important treatment consideration due to the complex interplay of physiologic changes associated with aging, co-morbidities, competing mortality, and potential differences in priorities among younger vs. older individuals when prognosis is limited. These issues are compounded by difficulty in predicting both benefit from chemotherapy and risk of toxicity in older patients due to historical underrepresentation in clinical trials $(9,10)$.

This narrative review will discuss the complexity of treating geriatric patients and outline the current state of evidence for the use of chemotherapy in this population for the treatment of advanced lung cancer.

\section{PHYSIOLOGIC CHANGES}

Physiologic changes with aging occur in a number of organ systems that can affect the safety of chemotherapy (Table 1). Glomerular filtration rate is typically estimated to decrease by $1 \mathrm{~mL} / \mathrm{min} /$ year beyond age 40 (11-14). In addition to this reduction in renal clearance, there is also impairment in the handling of water and electrolytes $(13,15)$. These changes can increase the risk to elderly lung cancer patients for toxicity from drugs primarily cleared by the kidneys, as well as dehydration and electrolyte imbalances.

The gastrointestinal system also changes with age, affecting drug absorption and the risk of mucositis $(16,17)$. Inconsistency in absorption results from reduced gastric blood flow, delayed gastric emptying, and a reduction in intestinal absorptive capacity (18-21). The vulnerability to mucosal injury arises from alteration of protective mechanisms, including a reduction in mucus and bicarbonate secretion (18). More importantly, elderly individuals generally show a decrease in hepatic mass and blood flow, which reduces drug metabolism (22). A reduction in activity of the cytochrome P450 system can also occur, resulting in a higher risk of drug interactions (23). The changes in metabolism can be further exacerbated by body composition changes that increase fat content and decrease water composition, thereby altering the volume of distribution for many drugs (24).

Finally, important changes occur in the bone marrow, with decreased cellularity, precursor proliferation, and cell mobilization $(25,26)$. These changes result in decreased bone marrow reserve. This altered bone marrow responsiveness increases the risk of marrow suppression and associated complications from chemotherapy and can delay further treatment administration $(27,28)$. 
Table 1 | Physiologic changes with aging

\begin{tabular}{|c|c|c|}
\hline Organ system & Changes & Effect on chemotherapy \\
\hline \multirow[t]{2}{*}{ Renal } & Decreased glomerular filtration & Decline in renal drug clearance that increases risk of drug toxicity \\
\hline & Impaired water and electrolyte handling & Increased risk of dehydration \\
\hline \multirow[t]{3}{*}{ Gastrointestinal } & Decreased gastric blood flow and delayed gastric emptying & Variable drug absorption \\
\hline & Decreased absorptive capacity & Decreased absorption of oral drugs \\
\hline & Decreased mucosal repair & Vulnerability to mucositis \\
\hline \multirow[t]{2}{*}{ Hepatobiliary } & Decreased liver mass and blood flow & Reduced hepatic metabolism \\
\hline & Reduction in cytochrome P450 activity & Greater vulnerability to P450 associated with drug interactions \\
\hline Body composition & Increased fat and decreased water & Changes drug volume of distribution \\
\hline Hematologic & Decreased marrow cellularity, proliferation, and mobilization & $\begin{array}{l}\text { Impaired response to cytopenias, delayed blood count recovery, } \\
\text { and higher risk of infection }\end{array}$ \\
\hline
\end{tabular}

\section{PREDICTION OF TOXICITY}

These physiologic shifts can increase the risk of chemotherapy toxicity in older individuals. However, clinical experience identifies many patients who seem much younger (or older) than their chronological age. This heterogeneity was strikingly demonstrated through comparison of life expectancies within geriatric age groups. Life expectancy for a 75-year-old woman ranged from 6.8 years (lowest 25 th percentile) to 17 years (highest 25th percentile) and the same values for a man are 4.9 and 14.2 years (29). This variation in life expectancy reflects differences in baseline health, comorbidity, and genetics (30). It seems reasonable to hypothesize that the individual with better life expectancy has less risk of toxicity and more chance of benefit from chemotherapy, since they have less risk of competing causes of mortality. The challenge is identifying these patients and improving the up to $44 \%$ of lung cancer patients $\geq 70$ years, who may require hospitalization during chemotherapy (31).

\section{COMPREHENSIVE GERIATRIC ASSESSMENT}

Historically, physicians used a combination of performance status (PS), measured using the Eastern Cooperative Oncology Group (ECOG) PS scale, and organ function as determined through blood work to determine, which patients qualified for chemotherapy treatment (32). This approach has been demonstrated to perform poorly when compared to more formal geriatric assessment (33-35). Comprehensive geriatric assessment (CGA) is usually composed of medical, functional, mental, social, and nutritional assessments, as well as explicit assessment of prescription drug use (36). A variety of studies have been completed to evaluate the usefulness of CGA in oncology patients. Systematic reviews of the available evidence show that CGA identifies problems that would otherwise be missed, leads to modifications in treatment plans, and helps predict toxicity from chemotherapy (37-42). Modification of treatment plans occurs in $21-53 \%$ of patients, suggesting that oncologists believe the additional information is valuable (42). CGA is also better than physician opinion for identifying frail elderly patients who experience greater toxicity (43). When tested in elderly NSCLC patients, CGA was feasible (44-46). Frail patients also exhibited poorer survival (46). However, when Corre et al. allocated patients to treatment based on CGA, survival was not different between groups, but toxicity was reduced in the arm allocating treatment using CGA (47).

\section{OTHER PREDICTIVE TOOLS}

While a CGA can be very useful, it has not become a routine part of oncologic care because it is time and labor intensive. The mean duration of CGA during one prospective study was $80 \mathrm{~min} /$ patient (48). Such a time commitment is difficult to undertake in lung cancer patients with metastatic disease, since it may delay patient throughput in clinic and/or delay commencement of treatment, a serious concern when patients have an average life expectancy of 10-12 months (8). In light of these concerns, a number of groups have attempted to shorten the CGA or provide a screening tool. Two groups have published new tools geared toward predicting chemotherapy toxicity and derived from multivariable analyses of CGAs conducted in cancer patients (Table 2) $(33,49)$. The chemotherapy risk assessment scale for high-age patients (CRASH) is actually composed of two scores, one for hematologic toxicity and another for non-hematologic toxicity (49). Diastolic blood pressure, instrumental activities of daily living (IADL), lactate dehydrogenase, and a proprietary Chemotox score help stratify the likelihood of experiencing Grade 3-4 hematologic toxicity into low (7\%), medium-low (23\%), medium-high (54\%), and high (100\%). For non-hematologic adverse events, the predictors are: ECOG PS, mini mental status, mini nutritional assessment, and the Chemotox score. The same predictive categories for non-hematologic toxicity predict risks of 33, 46, 67, and $93 \%$ (49). The Chemotox score is a quantitation of the toxicity of chemotherapy regimens that the group developed previously $(50,51)$. The cohort used for the CRASH score contained $21 \%$ lung cancer patients. The Cancer Aging Research Group (CARG) derived another predictive tool $(33,52)$. The CARG score uses 11 factors to stratify risk: age $\geq 72$, cancer type, standard chemotherapy dosing, polychemotherapy, low hemoglobin, low creatinine clearance, fair or worse hearing, falls, needing help with medications, trouble walking 1 block, and decreased social activity. 
Table 2 | Significant factors in scores predicting chemotherapy toxicity.

\begin{tabular}{lll}
\hline CRASH score (49) & Hematologic & Non-hematologic \\
\hline Diastolic blood pressure & $\begin{array}{l}\text { ECOG performance } \\
\text { status }\end{array}$ \\
IADL & Mini mental status \\
LDH & $\begin{array}{l}\text { Mini nutritional } \\
\text { assessment } \\
\text { Chemotox score }\end{array}$ & Chemotox score
\end{tabular}

\begin{tabular}{ll}
\hline CARG score (33) & Predictive factors \\
\hline Age $\geq 72$ years \\
Standard chemotherapy dosing \\
Multi-drug chemotherapy \\
Low hemoglobin \\
Low creatinine clearance \\
Decreased hearing \\
Fall within 6 months \\
Needs help taking medications \\
Limited in walking 1 block \\
Decreased social activity
\end{tabular}

$I A D L$, instrumental activities of daily living; $L D H$, lactate dehydrogenase; $E C O G$, Eastern Cooperative Oncology Group.

This score classified lung cancer patients into low (10\%), intermediate $(40 \%)$, or high $(60 \%)$ risk of Grade 3-5 toxicity (52). This score was better able to stratify risk of toxicity than Karnofsky PS alone. Both of these predictive tools are exciting because they provide information that can be used to discuss chemotherapy treatment with elderly patients. Unfortunately, neither has been validated outside of the initial population and, therefore, widespread adoption is not yet justified.

\section{EVIDENCE FOR CHEMOTHERAPY}

Since 1995, standard first line chemotherapy for younger patients with stage IV NSCLC has been a platinum doublet. The meta-analysis supporting this recommendation demonstrated a $10 \%$ improvement in 1-year survival for patients treated with chemotherapy compared to supportive care (53). However, the first randomized trial focusing specifically on elderly patients was not published until $1999(54,55)$. Since then, only a few randomized trials have been conducted in patients 70 years and older with metastatic NSCLC. Most recommendations have been based on subgroup analyses or cohort studies. This lower level of evidence has likely contributed to uncertainty among health professionals regarding the standard of care in these patients.

The primary trial investigating the utility of single-agent chemotherapy compared to the best supportive care in elderly patients with metastatic NSCLC was the Elderly Lung Cancer
Vinorelbine Italian Study (ELVIS) (55). The experimental arm of this RCT was single-agent vinorelbine $\left(30 \mathrm{mg} / \mathrm{m}^{2}\right)$ administered on days 1 and 8 of a 21-day cycle. This treatment resulted in an improvement in median survival (28 vs. 21 weeks) and 1-year survival (32 vs. $14 \%$ ), in addition to improvement in some lung cancer symptoms. Despite falling short of its 350 patient accrual target and closing prematurely, this established a new standard of care, which was incorporated as the control arm in further studies.

\section{DOUBLET CHEMOTHERAPY}

Subsequent trials have evaluated doublet chemotherapy regimens. Due to concerns about toxicity, these trials initially examined non-platinum chemotherapy combinations. The Southern Italy Cooperative Oncology Group (SICOG) conducted an RCT comparing gemcitabine and vinorelbine in combination to vinorelbine alone (56). The combination arm reported a median survival of 29 weeks compared to 18 weeks for vinorelbine alone. While this difference was statistically significant, there were concerns that the control group had worse survival than expected. These concerns prompted the multicenter Italian lung cancer in the elderly study (MILES), which compared three arms: vinorelbine plus gemcitabine, gemcitabine alone, and vinorelbine alone (57). Whereas, the SICOG trial enrolled 120 patients, MILES randomized 698 patients between the three arms. Median survivals were 30, 28, and 36 weeks for each of the arms, respectively. There was no statistically significant difference. There was, however, greater toxicity in the combination arm, specifically for neutropenia, thrombocytopenia, anemia, vomiting, constipation, and hepatic toxicity (57). These results do not support the use of the combination of vinorelbine and gemcitabine.

Further evaluation of doublet chemotherapy in patients $\geq 70$ years was pursued. In one RCT of elderly patients or those with ECOG PS 2, the combination of gemcitabine and paclitaxel improved median survival to 9.2 months compared with 5.1 months for gemcitabine alone (58). However, a RCT in the same mixed population comparing gemcitabine/docetaxel to weekly docetaxel reported no difference in survival (59). A systematic review with meta-analysis of RCTs comparing non-platinum doublets with single-agent therapy for elderly patients showed no survival advantage to doublet therapy and higher risk of thrombocytopenia (60). Perhaps the most promising regimen was the combination of carboplatin with paclitaxel. One phase II trial demonstrated that weekly paclitaxel combined with carboplatin resulted in a 14-month median survival with quite manageable toxicity (61). Interestingly, when compared to standard paclitaxel, weekly paclitaxel appears to have equivalent benefit, but reduces the risk of neutropenia and peripheral neuropathy (62). The landmark trial investigating the use of platinum doublets in the elderly is Intergroupe Francophone Cancérologie Thoracique (IFCT)0501 (63). This trial included 451 patients aged 70-89 years, with locally advanced or metastatic NSCLC and a PS of ECOG 0-2. Patients were randomized to carboplatin and weekly paclitaxel vs. monotherapy with either gemcitabine or vinorelbine. The trial was stopped early after interim analysis demonstrated superiority for the doublet regimen. Median overall survival was 10.3 months for carboplatin and paclitaxel compared to 6.2 months for monotherapy (hazard ratio $0.64,95 \%$ CI $0.52-0.78, p<0.0001$ ). The largest 
increases in toxicity for doublet chemotherapy were neutropenia (48.4 vs. $12.4 \%)$ and asthenia (10.3 vs. $5.8 \%)$ (63). Point estimates were quite consistent for all subgroups and multivariable analysis confirmed expected prognostic factors like sex, PS, adenocarcinoma histology, and smoking history.

One final trial, conducted in Japan by Takeda et al., has only been published in abstract form (64). The trial enrolled 276 patients, who were chemotherapy naïve, age $>70$ years, ECOG PS 0-1, and with stage III/IV NSCLC. Patients were randomized to receive either docetaxel every 3 weeks or weekly cisplatindocetaxel. Enrollment was stopped early due to futility, with median survival times of 13.3 months for cisplatin-docetaxel and 17.3 months for docetaxel alone (hazard ratio $1.557,95 \% \mathrm{CI}$ 0.976-2.485). Interestingly, neutropenia was far more common with docetaxel alone than the doublet regimen 88 vs. $11 \%$. The survival of the monotherapy group was remarkably high compared previous trials (65-67).

The majority of subgroup analyses from earlier trials suggest that survival is similar, though not always equal, between younger and older patients with advanced NSCLC who receive the same chemotherapy (68-71). The evidence suggests that the results of IFCT-0501 should form the standard of care for first line chemotherapy treatment in fit elderly patients with advanced NSCLC, especially when no molecular abnormalities are detected.

In the second line setting, there are no elder-specific trials. A retrospective analysis of the JMEI trial comparing docetaxel to pemetrexed was completed for patients $\geq 70$ years old vs. younger patients. Median survival of 9.5 and 7.7 months was reported for elderly patients receiving pemetrexed $(n=47)$ and docetaxel $(n=39)$. In younger patients, these values were 7.8 and 8.0 months. Febrile neutropenia occurred in only $2.5 \%$ of elderly patients receiving pemetrexed, but $19 \%$ of those being treated with docetaxel $(p=0.025)(72)$.

\section{TARGETED THERAPIES \\ BEVACIZUMAB}

Bevacizumab is a monoclonal antibody that targets vascular endothelial growth factor (VEGF) and can be used in combination with first line platinum-based chemotherapy. Two trials, ECOG 4599 and AVAiL, originally tested the addition of bevacizumab to standard chemotherapy $(73,74)$. Analyses of the elderly patients in both of these trials were conducted. The AVAiL trial, comparing cisplatin and gemcitabine with or without bevacizumab, showed no improvement in overall survival in the elderly population $(n=304)$, with the addition of bevacizumab (73). An analysis of patients $\geq 70$ years in the ECOG 4599 trial of carboplatin and paclitaxel with or without bevacizumab reported overall survival was 11.3 months with bevacizumab and 12.1 months without. There was a higher incidence of bleeding, neutropenia, and proteinuria in older compared to younger patients (74). There does not appear to be compelling evidence to include bevacizumab for those older than 65-70 years of age.

\section{EGFR TYROSINE KINASE INHIBITORS}

Molecularly defined subtypes of NSCLC have become incredibly important to management over the last 5 years. Epidermal growth factor receptor (EGFR) mutations are detected in approximately
$15 \%$ of Caucasian patients with advanced NSCLC and these mutations are found more often, but not exclusively in younger, never smoking women, or those of Asian ethnicity (75). The presence of an EGFR mutation is highly predictive of benefit from EGFR tyrosine kinase inhibitors (TKIs) (76). More widespread screening of all NSCLC tumor samples for molecular abnormalities will increase the number of EGFR mutations identified in the elderly. Available data demonstrate EGFR TKIs (erlotinib, gefitinib, or afatinib) result in better progression free survival (PFS) and favorable toxicity compared to chemotherapy in NSCLC patients with an EGFR mutation (76-79). While few studies have examined the effect of this strategy exclusively in elderly patients, available data would suggest that elderly patients have similar response rate and PFS (80-84). Toxicities reported were the expected diarrhea, rash, and risk of transaminitis.

The NCIC BR.21 trial evaluated erlotinib in NSCLC patients who progressed after one or two prior chemotherapy treatments regardless of EGFR mutation status. The improvement in overall survival was seen in both EGFR mutated and wild type patients. A retrospective analysis of treatment effect and age in BR.21 found no statistically significant difference in treatment effect between younger and older patients for overall survival. Elderly patients did experience more Grade 3-4 toxicity (35 vs. $18 \%$, $p<0.001$ ). Based on this subgroup analysis, erlotinib seems to be a reasonable option for elderly patients in the second or third line setting (85). A trial in vulnerable elderly patients by CGA adds further support to this opinion, since both gemcitabine followed by erlotinib or the reverse on progression showed similar survival and tolerability (45).

\section{ALK TYROSINE KINASE INHIBITORS}

The other actionable mutation found in NSCLC is a translocation in echinoderm microtubule associated protein-like 4 - anaplastic lymphoma kinase (EML4-ALK) gene, which is found in approximately $4 \%$ of patients with adenocarcinoma (75). Data in younger patients have been extremely promising with the use of crizotinib for EML4-ALK translocated NSCLC (86-88). Few patients were older than 70 years. A phase I study including 149 patients did report a response rate of $65 \%(40.8-84.6 \%)$ in patients $\geq 65$ years (87). More recently, two other early-phase clinical trials with different ALK TKIs demonstrated response rates $>50 \%$, with ceritinib showing impressive responses even in crizotinib resistant disease $(89,90)$. While there are little data in elderly patients, there is no reason to believe this group would derive less benefit from ALK TKI therapy.

\section{CONCLUSION}

An increasing proportion of patients with advanced NSCLC are over 70 years old, raising unique challenges for treatment decisionmaking. While these patients are underrepresented in clinical trials, there is an emerging body of evidence associated with this group. The lesson of CGA is that chronological age does not always correlate with physiological age and a variety of important co-morbidities and geriatric syndromes can go undetected in a typical history and physical. Geriatric assessment provides medical oncologists with information that can affect treatment decision and help predict chemotherapy toxicity. Abbreviated 
CGAs or newly derived tools offer the promise of more widespread implementation of appropriate assessment of elderly patients.

For patients fit enough to consider first line chemotherapy, a platinum doublet appears to be a reasonable standard of care. Adding bevacizumab does not appear to improve overall survival. In the second line, pemetrexed, docetaxel, or erlotinib are all options for consideration. Pemetrexed would be the preferred option for patients with non-squamous histology. For patients with EGFR mutated disease, using an EGFR TKI as a first line treatment is a reasonable approach, though there is little evidence specific to elderly populations.

Further research is needed on the validation of tools that predict chemotherapy toxicity and prognosis to facilitate informed consent and treatment decisions. More studies focusing on elderly patients are also essential to help account for the physiologic changes inherent in this population. As we move forward, medical oncology is becoming geriatric oncology in many ways.

\section{REFERENCES}

1. Turcotte M, Schellenber G. Demographic trends and the geography of aging. In: Canada S, editor. A Portrait of Seniors in Canada. Ottawa, ON: Minister of Industry (2007) p. 11-42.

2. Wang H, Dwyer-Lindgren L, Lofgren KT, Rajaratnam JK, Marcus JR, LevinRector A, et al. Age-specific and sex-specific mortality in 187 countries, 19702010: a systematic analysis for the global burden of disease study 2010. Lancet (2012) 380(9859):2071-94. doi:10.1016/S0140-6736(12)61719-X

3. Canadian Cancer Society's Steering Committee. Canadian Cancer Statistics 2010. Toronto, ON: Canadian Cancer Society, Statistics Canada, Public Health Agency of Canada (2010)

4. Jemal A, Bray F, Center MM, Ferlay J, Ward E, Forman D. Global cancer statistics. CA Cancer J Clin (2011) 61(2):69-90. doi:10.3322/caac.20107

5. Lozano R, Naghavi M, Foreman K, Lim S, Shibuya K, Aboyans V, et al. Global and regional mortality from 235 causes of death for 20 age groups in 1990 and 2010: a systematic analysis for the global burden of disease study 2010. Lancet (2012) 380(9859):2095-128. doi:10.1016/S0140-6736(12)61728-0

6. Govindan R, Page N, Morgensztern D, Read W, Tierney R, Vlahiotis A, et al. Changing epidemiology of small-cell lung cancer in the United States over the last 30 years: analysis of the surveillance, epidemiologic, and end results database. J Clin Oncol (2006) 24(28):4539-44. doi:10.1200/JCO.2005.04.4859

7. Owonikoko TK, Ragin CC, Belani CP, Oton AB, Gooding WE, Taioli E, et al. Lung cancer in elderly patients: an analysis of the surveillance, epidemiology, and end results database. J Clin Oncol (2007) 25(35):5570-7. doi:10.1200/JCO. 2007.12.5435

8. Howlader N, Noone AM, Krapcho M, Garshell J, Miller D, Altekruse SF, et al. SEER Cancer Statistics Review, 1975-2011. Bethesda, MD: National Cancer Institute (2014). Available from: http://seer.cancer.gov/csr/1975_2011/

9. Sacher AG, Le LW, Leighl NB, Coate LE. Elderly patients with advanced NSCLC in phase III clinical trials: are the elderly excluded from practice-changing trials in advanced NSCLC? J Thorac Oncol (2013) 8(3):366-8. doi:10.1097/JTO. 0b013e31827e2145

10. Hutchins LF, Unger JM, Crowley JJ, Coltman CA Jr, Albain KS. Underrepresentation of patients 65 years of age or older in cancer-treatment trials. $\mathrm{N} \mathrm{Engl} \mathrm{J}$ Med (1999) 341(27):2061-7. doi:10.1056/NEJM199912303412706

11. Sokoll LJ, Russell RM, Sadowski JA, Morrow FD. Establishment of creatinine clearance reference values for older women. Clin Chem (1994) 40(12):2276-81.

12. Rowe JW, Andres R, Tobin JD, Norris AH, Shock NW. The effect of age on creatinine clearance in men: a cross sectional and longitudinal study. J Gerontol (1976) 31(2):155-63. doi:10.1093/geronj/31.2.155

13. Lubran MM. Renal function in the elderly. Ann Clin Lab Sci (1995) 25(2):122-33.

14. Fehrman-Ekholm I, Skeppholm L. Renal function in the elderly (>70 years old) measured by means of lohexol clearance, serum creatinine, serum urea and estimated clearance. Scand J Urol Nephrol (2004) 38(1):73-7. doi:10.1080/ 00365590310015750
15. DeSanto NG, Anastasio P, Coppola S, Barba G, Jandanza A, Capasso G. Agerelated changes in renal reserve and renal tubular function in healthy humans. Child Nephrol Urol (1991) 11(1):33-40.

16. Sawhney R, Sehl M, Naeim A. Physiologic aspects of aging: impact on cancer management and decision making, part I. Cancer J (2005) 11(6):449-60. doi:10.1097/00130404-200511000-00004

17. Balducci L. Geriatric oncology. Crit Rev Oncol Hematol (2003) 46(3):211-20. doi:10.1016/S1040-8428(03)00020-9

18. Newton JL. Changes in upper gastrointestinal physiology with age. Mech Ageing $\operatorname{Dev}(2004)$ 125(12):867-70. doi:10.1016/j.mad.2004.05.007

19. Mayersohn M. The 'xylose test' to assess gastrointestinal absorption in the elderly: a pharmacokinetic evaluation of the literature. J Gerontol (1982) 37(3):300-5. doi:10.1093/geronj/37.3.300

20. Fabbri A, Marchesini G, Bianchi G, Bugianesi E, Zoli M, Pisi E. Kinetics of hepatic amino-nitrogen conversion in ageing man. Liver (1994) 14(6):288-94. doi:10.1111/j.1600-0676.1994.tb00091.x

21. Wegener M, Borsch G, Schaffstein J, Luth I, Rickels R, Ricken D. Effect of ageing on the gastro-intestinal transit of a lactulose-supplemented mixed solid-liquid meal in humans. Digestion (1988) 39(1):40-6. doi:10.1159/000199606

22. Wynne HA, Cope LH, Mutch E, Rawlins MD, Woodhouse KW, James OFW. The effect of age upon liver volume and apparent liver blood flow in healthy men. Hepatology (1989) 9(2):297-301. doi:10.1002/hep.1840090222

23. Wilcock A, Thomas J, Frisby J, Webster M, Keeley V, Finn G, et al. Potential for drug interactions involving cytochrome P450 in patients attending palliative day care centres: a multicentre audit. Br J Clin Pharmacol (2005) 60(3):326-9. doi:10.1111/j.1365-2125.2005.02428.x

24. Beaufrère B, Morio B. Fat and protein redistribution with aging: metabolic considerations. Eur J Clin Nutr (2000) 54(Suppl 3):S48-53. doi:10.1038/sj.ejcn. 1601025

25. Lipschitz DA, Udupa KB, Milton KY, Thompson CO. Effect of age on hematopoiesis in man. Blood (1984) 63(3):502-9.

26. Ogawa T, Kitagawa M, Hirokawa K. Age-related changes of human bone marrow: a histometric estimation of proliferative cells, apoptotic cells, T cells, B cells and macrophages. Mech Ageing Dev (2000) 117(1-3):57-68. doi:10.1016/ S0047-6374(00)00137-8

27. Zinzani PL, Pavone E, Storti S, Moretti L, Fattori PP, Guardigni L, et al. Randomized trial with or without granulocyte colony-stimulating factor as adjunct to induction VNCOP-B treatment of elderly high-grade non-Hodgkin's lymphoma. Blood (1997) 89(11):3974-9.

28. Gómez H, Mas L, Casanova L, Pen DLK, Santillana S, Valdivia S, et al. Elderly patients with aggressive non-Hodgkin's lymphoma treated with CHOP chemotherapy plus granulocyte-macrophage colony-stimulating factor: identification of two age subgroups with differing hematologic toxicity. J Clin Oncol (1998) 16(7):2352-8.

29. Walter LC, Covinsky KE. Cancer screening in elderly patients: a framework for individualized decision making. JAMA (2001) 285(21):2750-6. doi:10.1001/ jama.285.21.2750

30. Pallis AG, Hatse S, Brouwers B, Pawelec G, Falandry C, Wedding U, et al. Evaluating the physiological reserves of older patients with cancer: the value of potential biomarkers of aging? J Geriatr Oncol (2014) 5(2):204-18. doi:10.1016/ j.jgo.2013.09.001

31. Zauderer MG, Sima CS, Korc-Grodzicki B, Kris MG, Krug LM. Toxicity of initial chemotherapy in older patients with lung cancers. J Geriatr Oncol (2013) 4(1):64-70. doi:10.1016/j.jgo.2012.09.003

32. Orr ST, Aisner J. Performance status assessment among oncology patients: a review. Cancer Treat Rep (1986) 70(12):1423-9.

33. Hurria A, Togawa K, Mohile SG, Owusu C, Klepin HD, Gross CP, et al. Predicting chemotherapy toxicity in older adults with cancer: a prospective multicenter study. J Clin Oncol (2011) 29(25):3457-65. doi:10.1200/JCO.2011.34.7625

34. Repetto L, Fratino L, Audisio RA, Venturino A, Gianni W, Vercelli M, et al. Comprehensive geriatric assessment adds information to Eastern Cooperative Oncology Group performance status in elderly cancer patients: an Italian Group for Geriatric Oncology Study. J Clin Oncol (2002) 20(2):494-502. doi:10.1200/JCO.20.2.494

35. Wedding U, Kodding D, Pientka L, Steinmetz HT, Schmitz S. Physicians' judgement and comprehensive geriatric assessment (CGA) select different patients as fit for chemotherapy. Crit Rev Oncol Hematol (2007) 64(1):1-9. doi:10.1016/j.critrevonc.2007.05.001 
36. Maas HA, Janssen-Heijnen ML, Olde Rikkert MG, Machteld Wymenga AN. Comprehensive geriatric assessment and its clinical impact in oncology. Eur J Cancer (2007) 43(15):2161-9. doi:10.1016/j.ejca.2007.08.002

37. Puts MT, Hardt J, Monette J, Girre V, Springall E, Alibhai SM. Use of geriatric assessment for older adults in the oncology setting: a systematic review. J Natl Cancer Inst (2012) 104(15):1133-63. doi:10.1093/jnci/djs285

38. Ramjaun A, Nassif MO, Krotneva S, Huang AR, Meguerditchian AN. Improved targeting of cancer care for older patients: a systematic review of the utility of comprehensive geriatric assessment. J Geriatr Oncol (2013) 4(3):271-81. doi:10.1016/j.jgo.2013.04.002

39. Hamaker ME, Schiphorst AH, ten Bokkel Huinink D, Schaar C, van Munster BC. The effect of a geriatric evaluation on treatment decisions for older cancer patients - a systematic review. Acta Oncol (2014) 53(3):289-96. doi:10.3109/0284186X.2013.840741

40. Hamaker ME, Seynaeve C, Wymenga AN, van Tinteren H, Nortier JW, Maartense $\mathrm{E}$, et al. Baseline comprehensive geriatric assessment is associated with toxicity and survival in elderly metastatic breast cancer patients receiving single-agent chemotherapy: results from the OMEGA study of the Dutch Breast Cancer Trialists' Group. Breast (2014) 23(1):81-7. doi:10.1016/j.breast.2013.11.004

41. Puts MT, Santos B, Hardt J, Monette J, Girre V, Atenafu EG, et al. An update on a systematic review of the use of geriatric assessment for older adults in oncology. Ann Oncol (2014) 25(2):307-15. doi:10.1093/annonc/mdt386

42. Versteeg KS, Konings IR, Lagaay AM, van de Loosdrecht AA, Verheul HM. Prediction of treatment-related toxicity and outcome with geriatric assessment in elderly patients with solid malignancies treated with chemotherapy: a systematic review. Ann Oncol (2014). doi:10.1093/annonc/mdu052

43. Tucci A, Ferrari S, Bottelli C, Borlenghi E, Drera M, Rossi G. A comprehensive geriatric assessment is more effective than clinical judgment to identify elderly diffuse large cell lymphoma patients who benefit from aggressive therapy. Cancer (2009) 115(19):4547-53. doi:10.1002/cncr.24490

44. LeCaer H, Barlesi F, Corre R, Jullian H, Bota S, Falchero L, et al. A multicentre phase II randomised trial of weekly docetaxel/gemcitabine followed by erlotinib on progression, vs the reverse sequence, in elderly patients with advanced non small-cell lung cancer selected with a comprehensive geriatric assessment (the GFPC 0504 study). Br J Cancer (2011) 105(8):1123-30. doi:10.1038/bjc.2011.331

45. LeCaer H, Greillier L, Corre R, Jullian H, Crequit J, Falchero L, et al. A multicenter phase II randomized trial of gemcitabine followed by erlotinib at progression, versus the reverse sequence, in vulnerable elderly patients with advanced non small-cell lung cancer selected with a comprehensive geriatric assessment (the GFPC 0505 study). Lung Cancer (2012) 77(1):97-103. doi:10.1016/j.lungcan.2012.02.004

46. Gironés R, Torregrosa D, Maestu I, Gómez-Codina J, Tenias JM, Costa RR Comprehensive geriatric assessment (CGA) of elderly lung cancer patients: a single-center experience. J Geriatr Oncol (2012) 3(2):98-103. doi:10.1016/j.jgo. 2011.12.005

47. Corre R, Chouaid C, Greillier L, Le Caer H, Audigier-Valette C, Baize N, et al. Phase III, randomized, multicenter study comparing in elderly patients $(>70$ years) with stage iv non small-cell lung cancer (NSCLC) a standard strategy of treatment allocation (carboplatin based bi-therapy or monotherapy with docetaxel) based on performance status (PS) and age with an experimental strategy allocating the same chemotherapies or best supportive care (BSC) according to a comprehensive geriatric assessment (CGA)-study ESOGIA-GFPC-GECP 0802. Proceedings of the 15th World Conference on Lung Cancer; 2013 Oct 27-30; Sydney, NSW Australia: International Association for the Study of Lung Cancer (2013).

48. Horgan AM, Leighl NB, Coate L, Liu G, Palepu P, Knox JJ, et al. Impact and feasibility of a comprehensive geriatric assessment in the oncology setting: a pilot study. Am J Clin Oncol (2012) 35(4):322-8. doi:10.1097/COC. 0b013e318210f9ce

49. Extermann M, Boler I, Reich RR, Lyman GH, Brown RH, DeFelice J, et al. Predicting the risk of chemotherapy toxicity in older patients: the chemotherapy risk assessment scale for high-age patients (CRASH) score. Cancer (2012) 118(13):3377-86. doi:10.1002/cncr.26646

50. Extermann M, Bonetti M, Sledge GW, O'Dwyer PJ, Bonomi P, Benson AB III. MAX2 - a convenient index to estimate the average per patient risk for chemotherapy toxicity; validation in ECOG trials. Eur J Cancer (2004) 40(8):1193-8. doi:10.1016/j.ejca.2004.01.028
51. Extermann M, Chen H, Cantor AB, Corcoran MB, Meyer J, Grendys E, et al. Predictors of tolerance to chemotherapy in older cancer patients: a prospective pilot study. Eur J Cancer (2002) 38(11):1466-73. doi:10.1016/S0959-8049(02) 00090-4

52. Nie X, Liu D, Li Q, Bai C. Predicting chemotherapy toxicity in older adults with lung cancer. J Geriatr Oncol (2013) 4(4):334-9. doi:10.1016/j.jgo. 2013.05.002

53. Non-Small Cell Lung Cancer Collaborative Group. Chemotherapy in non-small cell lung cancer: a meta-analysis using updated data on individual patients from 52 randomised clinical trials. Non-small cell lung cancer collaborative group. BMJ (1995) 311(7010):899-909. doi:10.1136/bmj.311.7010.899

54. Rapp E, Pater JL, Willan A, Cormier Y, Murray N, Evans WK, et al. Chemotherapy can prolong survival in patients with advanced non-small-cell lung cancer - report of a Canadian multicenter randomized trial. J Clin Oncol (1988) 6(4):633-41.

55. Gridelli C. The ELVIS trial: a phase III study of single-agent vinorelbine as first-line treatment in elderly patients with advanced non-small cell lung cancer. Elderly Lung Cancer Vinorelbine Italian Study. Oncologist (2001) 6(Suppl 1):4-7. doi:10.1634/theoncologist.6-suppl_1-4

56. Frasci G, Lorusso V, Panza N, Comella P, Nicolella G, Bianco A, et al. Gemcitabine plus vinorelbine versus vinorelbine alone in elderly patients with advanced nonsmall-cell lung cancer. J Clin Oncol (2000) 18(13):2529-36.

57. Gridelli C, Perrone F, Gallo C, Cigolari S, Rossi A, Piantedosi F, et al. Chemotherapy for elderly patients with advanced non-small-cell lung cancer: the multicenter Italian lung cancer in the elderly study (MILES) phase III randomized trial. J Natl Cancer Inst (2003) 95(5):362-72. doi:10.1093/jnci/95. 5.362

58. Comella P, Frasci G, Carnicelli P, Massidda B, Buzzi F, Filippelli G, et al. Gemcitabine with either paclitaxel or vinorelbine vs paclitaxel or gemcitabine alone for elderly or unfit advanced non-small-cell lung cancer patients. Br J Cancer (2004) 91(3):489-97. doi:10.1038/sj.bjc.6602011

59. Hainsworth JD, Spigel DR, Farley C, Shipley DL, Bearden JD, Gandhi J, et al. Weekly docetaxel versus docetaxel/gemcitabine in the treatment of elderly or poor performance status patients with advanced nonsmall cell lung cancer: a randomized phase 3 trial of the Minnie Pearl Cancer Research Network. Cancer (2007) 110(9):2027-34. doi:10.1002/cncr.23019

60. Russo A, Rizzo S, Fulfaro F, Adamo V, Santini D, Vincenzi B, et al. Gemcitabinebased doublets versus single-agent therapy for elderly patients with advanced nonsmall cell lung cancer: a literature-based meta-analysis. Cancer (2009) 115(9):1924-31. doi:10.1002/cncr.24207

61. Inoue A, Usui K, Ishimoto O, Matsubara N, Tanaka M, Kanbe M, et al. A phase II study of weekly paclitaxel combined with carboplatin for elderly patients with advanced non-small cell lung cancer. Lung Cancer (2006) 52(1):83-7. doi:10.1016/j.lungcan.2005.11.014

62. Sakakibara T, Inoue A, Sugawara S, Maemondo M, Ishida T, Usui K, et al. Randomized phase II trial of weekly paclitaxel combined with carboplatin versus standard paclitaxel combined with carboplatin for elderly patients with advanced non-small-cell lung cancer. Ann Oncol (2010) 21(4):795-9. doi:10.1093/annonc/mdp401

63. Quoix E, Zalcman G, Oster J-P, Westeel V, Pichon E, Lavole A, et al. Carboplatin and weekly paclitaxel doublet chemotherapy compared with monotherapy in elderly patients with advanced non-small-cell lung cancer: IFCT-0501 randomised, phase 3 trial. Lancet (2011) 378(9796):1079-88. doi:10.1016/S01406736(11)60780-0

64. Takeda K, Abe T, Yokoyama A, Ohe Y, Kudoh S, Ichinose Y, et al. Randomized phase III trial comparing weekly docetaxel (DTX) and cisplatin (CDDP) combination (DP) with triweekly DTX alone in elderly patients with advanced nonsmall cell lung cancer (NSCLC): results of an intergroup trial of JCOG0803/WJOG4307L: International Association for the Study of Lung Cancer (2011). Available from: http://ovidsp.ovid.com/ovidweb.cgi?T=JS\&PAGE= reference $\& \mathrm{D}=$ emed $11 \& \mathrm{NEWS}=\mathrm{N} \& \mathrm{AN}=71235515$

65. Roszkowski K, Pluzanska A, Krzakowski M, Smith AP, Saigi E, Aasebo U, et al. A multicenter, randomized, phase III study of docetaxel plus best supportive care versus best supportive care in chemotherapy-naive patients with metastatic or non-resectable localized non-small cell lung cancer (NSCLC). Lung Cancer (2000) 27(3):145-57. doi:10.1016/S0169-5002(00)00094-5

66. Georgoulias V, Ardavanis A, Agelidou A, Agelidou M, Chandrinos V, Tsaroucha E, et al. Docetaxel versus docetaxel plus cisplatin as front-line treatment of patients 
with advanced non-small-cell lung cancer: a randomized, multicenter phase III trial. J Clin Oncol (2004) 22(13):2602-9. doi:10.1200/JCO.2004.11.004

67. Georgoulias V, Androulakis N, Kotsakis A, Hatzidaki D, Syrigos K, Polyzos A, et al. Docetaxel versus docetaxel plus gemcitabine as front-line treatment of patients with advanced non-small cell lung cancer: a randomized, multicenter phase III trial. Lung Cancer (2008) 59(1):57-63. doi:10.1016/j. lungcan.2007.07.021

68. Ansari RH, Socinski MA, Edelman MJ, Belani CP, Gonin R, Catalano RB, et al. A retrospective analysis of outcomes by age in a three-arm phase III trial of gemcitabine in combination with carboplatin or paclitaxel vs. paclitaxel plus carboplatin for advanced non-small cell lung cancer. Crit Rev Oncol Hematol (2011) 78(2):162-71. doi:10.1016/j.critrevonc.2010.03.003

69. Belani CP, Fossella F. Elderly subgroup analysis of a randomized phase III study of docetaxel plus platinum combinations versus vinorelbine plus cisplatin for first-line treatment of advanced nonsmall cell lung carcinoma (TAX 326). Cancer (2005) 104(12):2766-74. doi:10.1002/cncr.21495

70. Gridelli C, Brodowicz T, Langer CJ, Peterson P, Islam M, Guba SC, et al. Pemetrexed therapy in elderly patients with good performance status: analysis of two phase III trials of patients with nonsquamous non-small-cell lung cancer. Clin Lung Cancer (2012) 13(5):340-6. doi:10.1016/j.cllc.2011.12.002

71. Pallis AG, Karampeazis A, Vamvakas L, Vardakis N, Kotsakis A, Bozionelou V, et al. Efficacy and treatment tolerance in older patients with NSCLC: a metaanalysis of five phase III randomized trials conducted by the Hellenic Oncology Research Group. Ann Oncol (2011) 22(11):2448-55. doi:10.1093/annonc/ mdq772

72. Weiss GJ, Langer C, Rosell R, Hanna N, Shepherd F, Einhorn LH, et al. Elderly patients benefit from second-line cytotoxic chemotherapy: a subset analysis of a randomized phase III trial of pemetrexed compared with docetaxel in patients with previously treated advanced non-small-cell lung cancer. JClin Oncol (2006) 24(27):4405-11. doi:10.1200/JCO.2006.06.7835

73. Leighl NB, Zatloukal P, Mezger J, Ramlau R, Moore N, Reck M, et al. Efficacy and safety of bevacizumab-based therapy in elderly patients with advanced or recurrent nonsquamous non-small cell lung cancer in the phase III BO17704 study (AVAiL). J Thorac Oncol (2010) 5(12):1970-6. doi:10.1097/ JTO.0b013e3181f49c22

74. Ramalingam SS, Dahlberg SE, Langer CJ, Gray R, Belani CP, Brahmer JR, et al. Outcomes for elderly, advanced-stage non small-cell lung cancer patients treated with bevacizumab in combination with carboplatin and paclitaxel: analysis of Eastern Cooperative Oncology Group Trial 4599. J Clin Oncol (2008) 26(1):60-5. doi:10.1200/JCO.2007.13.1144

75. Cooper WA, Lam DC, O'Toole SA, Minna JD. Molecular biology of lung cancer. J Thorac Dis (2013) 5(Suppl 5):S479-90. doi:10.3978/j.issn.2072-1439.2013. 08.03

76. Lee CK, Brown C, Gralla RJ, Hirsh V, Thongprasert S, Tsai C-M, et al. Impact of EGFR inhibitor in non-small cell lung cancer on progression-free and overall survival: a meta-analysis. J Natl Cancer Inst (2013) 105(9):595-605. doi:10.1093/jnci/djt072

77. Ku GY, Haaland BA, de Lima Lopes G Jr. Gefitinib vs. chemotherapy as first-line therapy in advanced non-small cell lung cancer: meta-analysis of phase III trials. Lung Cancer (2011) 74(3):469-73. doi:10.1016/j.lungcan.2011.04.008

78. Rosell R, Carcereny E, Gervais R, Vergnenegre A, Massuti B, Felip E, et al. Erlotinib versus standard chemotherapy as first-line treatment for European patients with advanced EGFR mutation-positive non-small-cell lung cancer (EURTAC): a multicentre, open-label, randomised phase 3 trial. Lancet Oncol (2012) 13(3):239-46. doi:10.1016/S1470-2045(11)70393-X

79. Yang JC-H, Schuler MH, Yamamoto N, O’Byrne KJ, Hirsh V, Mok T, et al. LUXLung 3: a randomized, open-label, phase III study of afatinib versus pemetrexed and cisplatin as first-line treatment for patients with advanced adenocarcinoma of the lung harboring EGFR-activating mutations. ASCO Meeting Abstracts, Alexandria, VA (Vol. 30) (2012). p. LBA7500.
80. Tateishi K, Ichiyama T, Hirai K, Agatsuma T, Koyama S, Hachiya T, et al. Clinical outcomes in elderly patients administered gefitinib as first-line treatment in epidermal growth factor receptor-mutated non-small-cell lung cancer: retrospective analysis in a Nagano Lung Cancer Research Group study. Med Oncol (2013) 30(1):450. doi:10.1007/s12032-012-0450-2

81. Maemondo M, Minegishi Y, Inoue A, Kobayashi K, Harada M, Okinaga S, et al. First-line gefitinib in patients aged 75 or older with advanced non-small cell lung cancer harboring epidermal growth factor receptor mutations: NEJ 003 study. $J$ Thorac Oncol (2012) 7(9):1417-22. doi:10.1097/JTO.0b013e318260de8b

82. Ebi N, Semba H, Tokunaga SJ, Takayama K, Wataya H, Kuraki T, et al. A phase II trial of gefitinib monotherapy in chemotherapy-naive patients of 75 years or older with advanced non-small cell lung cancer. J Thorac Oncol (2008) 3(10):1166-71. doi:10.1097/JTO.0b013e318186a88d

83. Jackman DM, Yeap BY, Lindeman NI, Fidias P, Rabin MS, Temel J, et al. Phase II clinical trial of chemotherapy-naive patients $>$ or $=70$ years of age treated with erlotinib for advanced non-small-cell lung cancer. J Clin Oncol (2007) 25(7):760-6. doi:10.1200/JCO.2006.07.5754

84. Asami K, Koizumi T, Hirai K, Ameshima S, Tsukadaira A, Morozumi N, et al. Gefitinib as first-line treatment in elderly epidermal growth factor receptormutated patients with advanced lung adenocarcinoma: results of a Nagano Lung Cancer Research Group study. Clin Lung Cancer (2011) 12(6):387-92. doi:10.1016/j.cllc.2011.02.004

85. Wheatley-Price P, Ding K, Seymour L, Clark GM, Shepherd FA. Erlotinib for advanced non-small-cell lung cancer in the elderly: an analysis of the National Cancer Institute of Canada Clinical Trials Group Study BR.21. J Clin Oncol (2008) 26(14):2350-7. doi:10.1200/JCO.2007.15.2280

86. Shaw AT, Kim DW, Nakagawa K, Seto T, Crino L, Ahn MJ, et al. Crizotinib versus chemotherapy in advanced ALK-positive lung cancer. N Engl J Med (2013) 368(25):2385-94. doi:10.1056/NEJMoa1214886

87. Camidge DR, Bang YJ, Kwak EL, Iafrate AJ, Varella-Garcia M, Fox SB, et al. Activity and safety of crizotinib in patients with ALK-positive non-small-cell lung cancer: updated results from a phase 1 study. Lancet Oncol (2012) 13(10):1011-9. doi:10.1016/S1470-2045(12)70344-3

88. Shaw AT, Yeap BY, Mino-Kenudson M, Digumarthy SR, Costa DB, Heist RS, et al. Clinical features and outcome of patients with non-small-cell lung cancer who harbor EML4-ALK. J Clin Oncol (2009) 27(26):4247-53. doi:10.1200/JCO. 2009.22.6993

89. Seto T, Kiura K, Nishio M, Nakagawa K, Maemondo M, Inoue A, et al. CH5424802 (RO5424802) for patients with ALK-rearranged advanced nonsmall-cell lung cancer (AF-001JP study): a single-arm, open-label, phase 1-2 study. Lancet Oncol (2013) 14(7):590-8. doi:10.1016/S1470-2045(13)70142-6

90. Shaw AT, Kim DW, Mehra R, Tan DS, Felip E, Chow LQ, et al. Ceritinib in ALKrearranged non-small-cell lung cancer. N Engl J Med (2014) 370(13):1189-97. doi:10.1056/NEJMoa1311107

Conflict of Interest Statement: Dr. David E. Dawe has no conflicts of interest to report. Dr. Peter Michael Ellis reports having received honoraria from Lilly, Roche, and Boehringer Ingelheim for advisory boards.

Received: 01 May 2014; accepted: 25 June 2014; published online: 10 July 2014. Citation: Dawe DE and Ellis PM (2014) The treatment of metastatic non-small cell lung cancer in the elderly: an evidence-based approach. Front. Oncol. 4:178. doi: 10.3389/fonc.2014.00178

This article was submitted to Thoracic Oncology, a section of the journal Frontiers in Oncology.

Copyright $(2014$ Dawe and Ellis. This is an open-access article distributed under the terms of the Creative Commons Attribution License (CC BY). The use, distribution or reproduction in other forums is permitted, provided the original author(s) or licensor are credited and that the original publication in this journal is cited, in accordance with accepted academic practice. No use, distribution or reproduction is permitted which does not comply with these terms. 